\title{
Delayed Development of Resistance to QoI Fungicide in Venturia inaequalis in Israeli Apple Orchards and Improved Apple Scab Management Using Fungicide Mixtures
}

\author{
Lior Gur ${ }^{1,+} \oplus$, Keren Levy ${ }^{1, t, \neq}+\mathbb{C}$, Amotz Farber ${ }^{2}$, Omer Frenkel ${ }^{3}$ and Moshe Reuveni ${ }^{1, *}$ \\ 1 Shamir Research Institute, University of Haifa, P.O. Box 97, Katsrin 1290000, Israel; liogur@gmail.com (L.G.); \\ lilkreni@gmail.com (K.L.) \\ 2 Shahaf, Agricultural Services and Development, Kiryat Shmona 11603, Israel; am.farber@gmail.com \\ 3 Department of Plant Pathology and Weed Research, Agricultural Research Organization, The Volcani Center, \\ Rishon Lezyion 7505101, Israel; omerf@volcani.agri.gov.il \\ * Correspondence: mreuveni@research.haifa.ac.il \\ + These authors contributed equally. \\ $\ddagger$ Current address: Department of Zoology, Tel Aviv University, Tel Aviv 6977801, Israel.
}

check for updates

Citation: Gur, L.; Levy, K.; Farber, A.; Frenkel, O.; Reuveni, M. Delayed Development of Resistance to QoI Fungicide in Venturia inaequalis in Israeli Apple Orchards and Improved Apple Scab Management Using Fungicide Mixtures. Agronomy 2021, 11, 396. https://doi.org/10.3390/ agronomy11020396

Academic Editor: Karen Barry

Received: 21 January 2021

Accepted: 18 February 2021

Published: 23 February 2021

Publisher's Note: MDPI stays neutral with regard to jurisdictional claims in published maps and institutional affiliations.

Copyright: (c) 2021 by the authors. Licensee MDPI, Basel, Switzerland. This article is an open access article distributed under the terms and conditions of the Creative Commons Attribution (CC BY) license (https:/ / creativecommons.org/licenses/by/ $4.0 /)$.

\begin{abstract}
Quinone outside inhibitors (QoI) fungicides group were introduced for commercial use against apple scab (Venturia inaequalis) in Israel in 1997. Unlike other regions in the world, in which resistance of $V$. inaequalis to QoI fungicides was observed within 3-5 years of use, in Israel it only occurred after 14 years of use. Field trials conducted between 2007 and 2017 showed a significant reduction in susceptibility to QoIs in northern Israel only since 2011. The delay in the development of resistance is related to limited fungicidal sprays resulting from unfavorable conditions for the pathogen. Of the 28 isolates collected from infected leaves or fruits of commercial orchards in northern Israel, 27 were resistant to the QoI fungicide Kresoxim-methyl. Amplification of the CYTB gene and sequencing of the G143A mutation region confirmed the resistance of all 27 isolates to QoIs. Resistance is demonstrated in the orchard, in vitro and molecular-based study, which forced the growers to avoid using QoIs against apple scab. We show that foliar applications of tank mixtures of systemic fungicides plus captan or prepacked fungicidal mixtures improved efficacy and can be used as a strategic approach in fungicide resistance management, including in orchards in which resistance to QoIs has been detected.
\end{abstract}

Keywords: apple scab management; fungicide resistance; quinone outside inhibitors; Malus domestica; strobilurins; susceptibility

\section{Introduction}

Apple scab, caused by the fungus Venturia inaequalis (Cke.) Wint is one of the most economically important diseases of cultivated apple (Malus domestica Borkh.) worldwide [1,2]. Severe crop losses in susceptible cultivars can occur when appropriate control measures are not taken, especially when the spring and summer seasons are moist, and the temperature is favorable for the disease [1]. The fungus infects leaves, shoots, buds, blossoms and fruit and can reduce fruit quality and size. It can also cause premature fruit drop, defoliation and poor development of fruit buds in the following season [2]. The potential of infection can be overcome mainly by a costly spraying program, labor, machinery and a pesticides regime [1,3].

Increased damage due to apple scab occurred in recent years in Israel. Most of the damage was observed to Red Delicious and cv. Pink Lady apple cultivars, which are among the important varieties in Israel. This damage resulted in up to $60 \%$ crop losses in some orchards in the Northern Golan region [4]. Apple scab infections also reappeared after more than 15 years, in areas such as the Upper Galilee. This could be due to a combination 
of multiple rain events in the spring, inappropriate timing of the applications and the use of ineffective fungicides.

Strobilurins (Quinone outside inhibitors-QoI) were considered the most effective fungicide group against apple scab in Israel and other Mediterranean countries [5,6]. QoI fungicides inhibit cell respiration by binding at the ubiquinol oxidation in the mitochondrial cytochrome bc1 complex [7]. QoI resistance was reported in several plant pathogens [8-10]. Resistance is related to a single point mutation in the mitochondrial cytochrome b (CYTB) gene causing a change of the amino acid Glycine $(\mathrm{G})$ to Alanine $(\mathrm{A})$ at position $143(\mathrm{G} 143 \mathrm{~A})$ of the protein [11]. Isolates of $V$. inaequalis resistant to QoI fungicides are known in the world for some time [12,13]. QoI resistance of $V$. inaequalis was first reported in 1997 in a European field and in experimental trials [14]. Köller et al. [15] showed that $V$. inaequalis isolates collected from a Michigan apple orchard exhibited decreased sensitivity to this class of fungicides after only 4 years of strobilurin use. Since then, more studies from various countries have reported resistance of $V$. inaequalis to QoIs [13-18].

Weather conditions in Central/Western European countries as well as in Northeastern United States and Canada, where rain is prevalent from spring to late autumn with concomitant warm temperatures, promote apple scab proliferation. Therefore, disease resistance is prevalent due to intensive pesticide spray programs, which span almost the entire year [2]. On the other hand, the Mediterranean climate in Israel, including cold and rainy winters, mild springs with limited rain events and dry summers, led growers to use limited fungicidal sprays. This has resulted in sufficient apple scab control in most years and should have reduced the risk of development of fungicide resistance. Nevertheless, the last several years demonstrated an increase in damaged apple orchards induced by apple scab infection. Observations made since 2011 suggested reduced sensitivity to stobilurins in Northern Israel [4].

The scarcity of research and knowledge on the extent of QoI resistance in Israel and other limited reports from Mediterranean climatic regions, along with the lack of knowledge on other types of effective fungicides which have different modes of action, forced growers to rely on strobilurin applications in critical infection periods, even though their efficacy was relatively low. This seems to be similar in other parts of the Mediterranean region characterized by relatively limited rain events [19,20]. Due to this lack of knowledge and control solutions, the main objectives of this work were (i) to confirm and determine the time of occurrence of $V$. inaequalis resistance to QoI fungicides in Israeli Mediterranean climate in relation to other climatic regions of the world and (ii) to examine and suggest fungicidal mixtures as a strategic approach for effective disease management.

\section{Materials and Methods}

\subsection{Fungicides}

The activities and efficacy of the following fungicides (Table 1) were examined in order to study fungicide resistance in laboratory experiments and field trials: the strobilurins (QoI) kresoxim-methyl and trifloxystrobin, the sterol demethylation inhibitors (DMI) difenoconazole and cyproconazole, the multisite fungicide captan. The activity of the following prepacked mixtures was also examined, as a strategy for improving efficacy: captan plus tebuconazole, boscalid plus trifloxystrobin, cyprodinil plus tebuconazole, pyraclostrobin plus boscalid, fluopyram plus tebuconazole (Table 1).

\subsection{Field Trials}

Field trials with the apple "Starking", "Anna" and "Odem" cultivars were conducted in commercial orchards in the major growing regions in Northern Golan and Upper Galilee of Israel (Figure S1). These cultivars are susceptible to apple scab, which was prevalent in these orchards in previous years [21]. Fertilization, irrigation and other cultural practices were recommended to commercial growers by the Extension Service of the Israeli Ministry of Agriculture. The annual rainfall in this region is 750-850 mm (Israel Meteorological Service, www.ims.gov.il (accessed on 6 September 2020)), all of which occurs during 
the winter period (October-April). During the spring (April-May), temperatures are moderate $\left(10-25^{\circ} \mathrm{C}\right)$ and wetness conditions due to rain events are favorable for fungal infection [1]. In the summer (June-September), the average midday relative humidity $(\mathrm{RH})$ and temperature are $35-40 \%$ and $30{ }^{\circ} \mathrm{C}$, respectively. The skies are cloudless during most of the summer. Night temperatures occasionally fall to $14-20^{\circ} \mathrm{C}$ between the end of May-August, and dew may accumulate on the leaf surfaces during some nights.

Table 1. List of the fungicides used in the laboratory experiments and the field trials.

\begin{tabular}{|c|c|c|c|c|c|c|}
\hline Product Name & $\begin{array}{c}\text { Active } \\
\text { Ingredient }\end{array}$ & $\begin{array}{l}\% \text { Active } \\
\text { Ingredient }\end{array}$ & Formulation ${ }^{1}$ & Producer and Country & Fungicide Group ${ }^{2}$ & FRAC Code \\
\hline Stroby & Kresoxim-methyl & 50 & WG & \multirow{2}{*}{$\begin{array}{c}\text { BASF, Germany } \\
\text { Bayer CropScience Ltd., } \\
\text { Germany }\end{array}$} & QoI & 11 \\
\hline Flint & Trifloxystrobin & 50 & WG & & QoI & 11 \\
\hline Score & Difenoconazole & 25 & SC & Syngenta, Switzerland & DMI & 3 \\
\hline Atemi-Extra & Cyproconazole & 10 & SC & Syngenta, Switzerland & DMI & 3 \\
\hline Merpan & Captan & 50 & WP & $\begin{array}{c}\text { Adama Makhteshim, } \\
\text { Israel }\end{array}$ & multi-site & M04 \\
\hline Orpan & $\begin{array}{c}\text { Captan }+ \\
\text { tebuconazole }\end{array}$ & $32+8$ & SC & $\begin{array}{c}\text { Adama Makhteshim, } \\
\text { Israel }\end{array}$ & multi-site + DMI & $\mathrm{M} 04+3$ \\
\hline Discovery & $\begin{array}{l}\text { Boscalid + } \\
\text { trifloxystrobin }\end{array}$ & $17.7+10$ & SC & Tapazole, Israel & $\mathrm{SDHI}+\mathrm{QoI}$ & $7+11$ \\
\hline Benelus & $\begin{array}{l}\text { Cyprodinil + } \\
\text { tebuconazole }\end{array}$ & $18.75+12.5$ & $\mathrm{EC}$ & $\begin{array}{c}\text { Adama Makhteshim, } \\
\text { Israel }\end{array}$ & $\mathrm{AP}+\mathrm{DMI}$ & $9+3$ \\
\hline Bellis & $\begin{array}{l}\text { Pyraclostrobin }+ \\
\text { boscalid }\end{array}$ & $12.8+25.2$ & WG & BASF, Germany & QoI + SDHI & $11+7$ \\
\hline Luna Experience & $\begin{array}{l}\text { Fluopyram + } \\
\text { tebuconazole }\end{array}$ & $20+20$ & SC & $\begin{array}{c}\text { Bayer CropScience Ltd., } \\
\text { Germany }\end{array}$ & $\mathrm{SDHI}+\mathrm{DMI}$ & $7+3$ \\
\hline
\end{tabular}

${ }^{1} \mathrm{WG}=$ water dispersible granules, $\mathrm{SC}=$ suspension concentrate, $\mathrm{WP}=$ wettable powder, $\mathrm{EC}=$ emulsifiable concentrate. ${ }^{2} \mathrm{QoI}=\mathrm{quinone}$ outside inhibitors, DMI = demethylation inhibitor, $\mathrm{SDHI}=$ succinate dehydrogenase inhibitors, $\mathrm{AP}=$ anilino pyrimidines.

\subsubsection{Experimental Design of Field Trials}

Application of fungicides began at the green leaf tip stage (BBCH-09) (unless otherwise stated). Fungicides were sprayed to runoff with a Turbo 400 (100-L, $1400 \mathrm{kPa})$ gun sprayer (Degania Sprayers, Degania, Israel) at spray volumes of $800-1000 \mathrm{~L} \mathrm{ha}^{-1}$, according to the size of the trees, at the time intervals specified for each trial based on phenological stage and rain events basis. Spacing between rows and trees was $4 \times 2 \mathrm{~m}$ or $4 \times 1.5 \mathrm{~m}$. Treatments in all field trials were performed using a randomized complete block design. Each replicate was comprised of two or three trees, with four replicates for each treatment.

\subsubsection{Changes in the Efficacy of QoI Fungicides in the Control of Apple Scab}

In order to monitor the changes in the efficacy of QoI fungicides against $V$. inaequalis, the efficacy of kresoxim-methyl spraying trees compared to control untreated trees was tested in 17 field trials from 2007 to 2017 (numbers in parenthesis indicates number of experiments conducted in each year: $2007(n=1), 2010(n=1), 2011(n=3), 2012(n=2)$, $2013(n=2), 2014(n=2), 2015(n=3), 2016(n=1), 2017(n=2))$ in various orchards in Northern Israel. Field trials in all these orchards were conducted to evaluate the efficacy of kresoxim-methyl applied alone at the recommended concentration $(0.015 \% v / v)$ to each of three trees, in four replicated plots as described below, compared to untreated trees. Disease was assessed on leaves and/or fruits as described below, and percent efficacy compared to the control was calculated.

2.2.3. Relationship between Average Rainfall ( $\mathrm{mm}$ ) in Season, Number of QoI Sprays per Season and Years until Occurrence of Resistance to QoI

A literature review of studies reporting the appearance of resistance of $V$. inaequalis to QoI fungicides was conducted. Data from representative countries from Europe, North America and South America was reviewed. For each study, the following parameters were documented: year of QoI resistance appearance, number of years of QoI use until resistance appeared, number of QoI sprays per season and average rainfall $(\mathrm{mm})$ in the 
four months of the growing season, in which the most susceptible phenological stages exist. The correlation between the average number of QoI sprays per season and the years of QoI use until resistance appeared was calculated using logarithmic regression in the Excel 2016 software package, (Microsoft Inc., Redlands, WA, USA).

\subsubsection{Field Trials to Examine the Efficacy of QoI Fungicides against Apple Scab}

During the years 2010, 2011, 2015, 2016 and 2017, field trials were conducted using cvs. Starking $(n=5)$, Odem $(n=1)$ and Anna $(n=1)$ apple orchards. Seven trials were conducted to evaluate the efficacy of QoI fungicides to control apple scab, compared to DMI fungicides and fungicidal mixtures. Untreated trees served as controls. The fungicides were applied at recommended concentrations and applications were dated according to rain events. Details on each trial are summarized in Table 2.

Table 2. Field trials conducted to assess the efficacy of strobilurin and triazole fungicides against V. inaequalis.

\begin{tabular}{|c|c|c|c|c|c|c|c|c|c|}
\hline Trial & Year & Location, Region & Treatments ${ }^{1}$ & $\begin{array}{l}\text { Apple } \\
\text { Cultivar }\end{array}$ & $\begin{array}{l}\text { Age of Trees } \\
\text { (Years) }\end{array}$ & Rootstock & $\begin{array}{c}\text { \# of } \\
\text { Sprays }\end{array}$ & $\begin{array}{l}\text { Beginning } \\
\text { of Sprays }\end{array}$ & $\begin{array}{l}\text { End of } \\
\text { Sprays }\end{array}$ \\
\hline 1 & 2010 & Majdal-Shams, Golan & $\begin{array}{c}\text { Stroby }(0.015 \%)+\text { Merpan } \\
(0.25 \%) \text {, Orpan }(0.3 \%) \text {, Merpan } \\
(0.25 \%) \text {, Control untreated }\end{array}$ & Starking & 13 & MM.106 & 6 & $\begin{array}{c}\text { March } 18 \\
\left(\mathrm{BBCH}-09^{2}\right)\end{array}$ & June 6 \\
\hline 2 & 2011 & $\begin{array}{l}\text { Alonei-Ha'bashan, } \\
\text { Golan }\end{array}$ & $\begin{array}{c}\text { Stroby }(0.015 \%)+\text { Merpan } \\
(0.25 \%) \text {, Orpan }(0.3 \%) \text {, Merpan } \\
(0.25 \%) \text {, Control untreated }\end{array}$ & Starking & 7 & $\begin{array}{l}\text { Hashabi } \\
\text { (local } \\
\text { rootstock) }\end{array}$ & 7 & $\begin{array}{c}\text { April } 8 \\
(\mathrm{BBCH}-09)\end{array}$ & June 1 \\
\hline 3 & 2011 & Sha'al, Golan & $\begin{array}{c}\text { Stroby }(0.015 \%) \text {, Orpan }(0.3 \%) \text {, } \\
\text { Control untreated }\end{array}$ & Starking & 8 & MM.106 & 6 & $\begin{array}{c}\text { April 13 } \\
\text { (BBCH-11) }\end{array}$ & May 25 \\
\hline 4 & 2011 & Kidmat-Tzvi, Golan & $\begin{array}{c}\text { Stroby }(0.015 \%), \text { Control } \\
\text { untreated }\end{array}$ & Starking & 3 & MM.106 & 6 & $\begin{array}{l}\text { April 13 } \\
\text { (BBCH-11) }\end{array}$ & May 25 \\
\hline 5 & 2015 & $\begin{array}{l}\text { Alonei-Ha'bashan, } \\
\text { Golan }\end{array}$ & $\begin{array}{c}\text { Flint }(0.015 \%), \\
\text { Bellis }(0.05 \%), \\
\text { Control untreated }\end{array}$ & Starking & 11 & MM.106 & 4 & $\begin{array}{l}\text { March 29 } \\
\text { (BBCH-09) }\end{array}$ & April 20 \\
\hline 6 & 2016 & Yesud HaMa'ala, Gallile & $\begin{array}{c}\text { Stroby }(0.015 \%) \text {, Score }(0.01 \%) \text {, } \\
\text { Control untreated }\end{array}$ & Odem & 3 & MM.106 & 3 & $\begin{array}{l}\text { March 13 } \\
\text { (BBCH-09) }\end{array}$ & April 11 \\
\hline 7 & 2017 & $\begin{array}{l}\text { Kadesh valley, } \\
\text { Upper Gallile }\end{array}$ & $\begin{array}{l}\text { Stroby }(0.015 \%), \text { Atemi Extra } \\
(0.03 \%), \text { Control untreated }\end{array}$ & Anna & 12 & $\begin{array}{l}\text { Hashabi } \\
\text { (local } \\
\text { rootstock) }\end{array}$ & 5 & $\begin{array}{l}\text { March 13 } \\
\text { (BBCH-09) }\end{array}$ & April 13 \\
\hline
\end{tabular}

\footnotetext{
${ }^{1}$ In every experiment, each treatment (fungicide) was applied solely at 3-7 sprays (according to each experiment) on the same trees.
}

2 BBCH-09 = Green tip stage, BBCH-11 = First unfolded leaf stage.

\subsection{Activity of QoI Fungicides on Mycelial Growth of V. inaequalis In Vitro}

\subsubsection{Collection of Fungal Isolates}

Twenty-eight $V$. inaequalis isolates were collected during the 2014-2015 seasons. Isolates were collected from infected apple fruits and leaves of cv. Red Delicious Starking in nine different orchards in Northern Israel (The Golan, Upper Galilee and Hula Valley), the main growing region in Israel (Figure S1 and Table S1). Isolation of fungal isolates was made according to Gur et al. [22] with some modification. Briefly, scab infected leaves and fruits were sprayed with $90 \%$ ethanol. Small pieces $(1-2 \mathrm{~mm})$ of the infected leaf or fruit tissue, adjacent to the scab lesions, were removed and placed in a 1\% Sodium hypochlorite solution for three minutes, washed twice with sterilized water and placed again in 1\% Sodium hypochlorite solution for another $30 \mathrm{~s}$, and washed again. Pieces were placed on Petri dishes containing potato dextrose agar (PDA, $39 \mathrm{~g} \mathrm{~L}^{-1}$, Difco) and chloramphenicol at $200 \mu \mathrm{g}^{-1}$ and were incubated in the dark at $24{ }^{\circ} \mathrm{C}$ for at least two weeks for fungal development. Agar disks, $2 \mathrm{~mm}$ in diameter, bearing single hypha of $V$. inaequalis were taken from the edge of a freshly growing colony and placed on new Petri dishes containing PDA and the developed colonies were used for further experiments.

\subsubsection{Inhibition of Mycelial Growth of $V$. inaequalis In Vitro}

The activity of kresoxim-methyl and difenoconazole was tested against ten $V$. inaequalis isolates representing the nine orchards from which 28 isolates were collected (preliminary observations showed no differences regarding to QoI sensitivity, in isolates from the same orchards). Agar disks, $2 \mathrm{~mm}$ in diameter, bearing $V$. inaequalis were taken from the edge of a freshly growing colony and placed on PDA amended with kresoxim-methyl at $75 \mu \mathrm{g}$ 
$\mathrm{ml}^{-1}$ and difenoconazole at $50 \mu \mathrm{g} \mathrm{ml}^{-1}$, or PDA alone as control, in 9-cm Petri dishes, with four discs in each dish. Three dishes per treatment were incubated at $25^{\circ} \mathrm{C}$ in the dark, and colony diameters were recorded 16 days after inoculation. Percent efficacy of each fungicide relative to the control was calculated, and accordingly, the degree of susceptibility to either kresoxim-methyl or difenoconazole was determined. A scale to determine the degree of resistance or susceptibility was prepared as follows: Resistant (0-30\% efficacy), Moderate resistant (30-75\% efficacy) and Susceptible ( $>75 \%$ efficacy).

In another experiment, the sensitivity of the isolate V.i-AL-f collected in 2014 from the Alonei Ha'bashan orchard, one of the most infected areas in Northern Israel, was tested. The experiment was conducted in order to examine sensitivity to additional fungicides, such as trifloxystrobin and captan. Agar disks, $2 \mathrm{~mm}$ in diameter, bearing $V$. inaequalis were placed on PDA amended with various concentrations of each fungicide in 9-cm Petri dishes, with four discs in each dish. The fungicides included: kresoxim-methyl (at final concentrations of $0.75,7.5$ and $75 \mu \mathrm{g} \mathrm{ml}^{-1}$ a.i.), trifloxystrobin $\left(0.75,7.5\right.$ and $75 \mu \mathrm{g} \mathrm{ml}^{-1}$ a.i.), difenoconazole $\left(0.5,5\right.$ and $50 \mu \mathrm{g} \mathrm{ml}^{-1}$ a.i. $)$ and captan $\left(12,120\right.$ and $1200 \mu \mathrm{g} \mathrm{ml}^{-1}$ a.i.) Three dishes per treatment were incubated at $25^{\circ} \mathrm{C}$ in the dark and colony diameters were recorded on day 16 post-inoculation. EC $_{50}$ values (the concentration of each fungicide causing 50\% inhibition) were calculated.

On a third experiment, the activity of kresoxim-methyl on mycelial growth of isolate from the deserted untreated orchard (V.i-Bq-No-l-d) vs. three isolates (V.i-Bq-Mn-l-d, ViYm-f and Vi-Sh-f) from three highly infected orchards, despite QoI sprays in previous years, was also examined. Various concentrations of kresoxim-methyl $(0,0.75,7.5,75$, 750 and $7500 \mu \mathrm{g} \mathrm{ml}^{-1}$ a.i.) were tested for each isolate in Petri dishes. Three dishes per treatment were incubated at $25{ }^{\circ} \mathrm{C}$ in the dark and colony diameters were recorded on day 14 post-inoculation.

\subsection{PCR-Based Detection of the G143A Mutation in V. inaequalis}

In order to detect the G143A mutation via the PCR detection method, the DNA of 28 isolates was extracted from pure cultures of both QoI-sensitive and resistant $V$. inaequalis isolates. DNA was extracted from mycelia using the MastePure yeast DNA extraction kit (Epicenter, WI, USA), according to the manufacturer's protocol. An allele-specific PCR (AS-PCR) reaction was conducted containing primers designed by Fontaine et al. [13]. The forward primer PS1 and the reverse primer G143AMM1 were used to amplify a $433 \mathrm{bp}$ DNA fragment encompassing the amino acid 143 codon of the cytochrome $b$ gene (CYTB). All AS-PCR reactions included a second set of primers as an amplification control: PS-exon7 and PR-exon7. This primer pair is specific for $V$. inaequalis CYTB alleles and was used as a control to amplify a $238 \mathrm{bp}$ fragment in a ubiquitous region $5 \mathrm{~kb}$ downstream from the G143 mutation. The PCR reaction was performed as described by Fontaine et al. [13], with some modifications. A $25 \mu \mathrm{L}$ reaction volume contained $0.4 \mu \mathrm{M}$ of allele-specific primers (PS1 and G143AMM1) and $0.2 \mu \mathrm{M}$ of control primers (PS-exon7 and PR-exon7), $12.5 \mu \mathrm{L}$ of DreamTaqTM Green PCR Master Mix $(2 \times)$ (Thermo Scientific, CA, USA), $1 \mu \mathrm{L}$ of genomic DNA and $10.9 \mu \mathrm{L}$ of DNase free water. Amplifications were performed according to Fontaine et al. [13]. PCR products were separated on 1.5\% agarose gel in $1 \times \mathrm{TAE}$ at $100 \mathrm{~V}$ for $25 \mathrm{~min}$ and stained with ethidium bromide. Photograph of the gel was taken on an EnduroTM GDS Gel documentation system (Labnet International Inc., NJ, USA).

\subsection{Molecular Detection of the G143A CYTB Gene Mutation by Direct Sequencing}

In order to determine the presence of the G143A mutation in each of the 28 isolates and to screen for additional SNPs (Single nucleotide polymorphism) in the CYTB gene from Israeli populations, V. inaequalis CYTB-specific primers ViCytB-5F and ViCytB-6071R, according to Villani and Cox [23], were used to generate a 938 bp DNA fragment that included codon 143. The PCR reaction was performed as described by Villani and Cox [23]. PCR products were sequenced (Macrogen Inc., Amsterdam, The Netherlands). The $938 \mathrm{bp}$ DNA fragment sequences of the 28 Israeli isolates were compared to a $V$. inaequalis reference 
isolate (GenBank Accession No. AF004559) derived from the National Center for Biotechnology Information (NCBI, National Library of Medicine, USA, http: / / www.ncbi.nlm.nih.gov (accessed on 6 September 2020)). Multiple nucleotide sequence alignments were performed using ClustalW (BioEdit v7.0.1, CA, USA).

\subsection{Use of Fungicidal Mixtures for Improving Efficacy against $V$. inaequalis}

2.6.1. Use of Fungicidal Mixtures for Improving Efficacy In Vitro

The in vitro activity of the prepacked mixtures tebuconazole plus captan (Orpan), cyprodinil plus tebuconazole (Benelus) and pyraclostrobin plus boscalid (Bellis) was tested against mycelial growth of the $V$. inaequalis isolate V.i-Al-f. The mixtures efficacy was compared to that of kresoxim-methyl and trifloxystrobin. Experiment was conducted as described in Section 2.3.2.

\subsubsection{Use of Fungicidal Mixtures for Improving Efficacy in Field Trials}

Two field trials were conducted in order to examine the efficacy of fungicidal mixtures, in addition to the 7 field trials conducted to examine the efficacy of QoI fungicides. The first trial was undertaken during 2015 in a Buq'ata orchard in the Northern Golan region on 26-year-old "Starking" trees grafted on Hashabi rootstock and examined the efficacy of kresoxim-methyl (Stroby) (0.015\% v/v) applied alone, compared to prepacked fungicidal mixtures of tebuconazole plus captan (Orpan) $(0.3 \% v / v)$ and trifloxystrobin with boscalid (Discovery) $(0.075 \%$ v/v), as described in the above Section 2.2.2 of Materials and Methods.

The second trial was conducted during 2017 at the Matityahu Experimental Station orchard in the Upper Galilee. In this trial, the treatments were applied to 7-year-old "Starking" trees grafted on MM.106 rootstock. The efficacy of eight fungicides and mixtures against apple scab, given in Section 3.7, was evaluated. Untreated trees served as controls. Three foliar sprays of each fungicide/mixture were applied on March 28 (Green Tip (BBCH09), 12 April and 16 May, according to rain events. Each replicate was comprised of three trees, with four replicates per treatment.

\subsection{Assessment of Fruits and Leaves Infected with Apple Scab}

Ten to 14 days after the last application, disease was assessed in each of four replicates in each treatment. Scab lesions on leaves were assessed on ten randomly selected shoots from each side of each central tree of each replicate. In each shoot, the number of infected leaves per each of five leaves (position 4-8) was determined (total of 100 leaves per replication, 400 leaves per treatment). In some cases, the percentage of infected leaf area was also determined. The incidence of apple scab on fruits was assessed by counting the number of infected fruits out of 25 randomly selected fruits on each side of the central tree of each replicate (200 fruits per treatment).

\subsection{Data Analysis}

Each laboratory experiment was conducted at least twice. Data from repeated experiments were combined for analysis when the variance between experiments was homogeneous. All data were analyzed using the JMP statistics package version 14.1.0 (SAS, Cary, $\mathrm{NC}, \mathrm{USA})$. The $\mathrm{EC}_{50}$ values for mycelial growth were calculated by Probit analysis using the SPSS software (IBM SPSS Statistics 20.0). For field trials, analysis of variance (ANOVA) was subjected to arcsin transformed data of the percentage of infected leaves or fruits, in order to achieve a normal distribution. Data in the tables are reported in untransformed units. Fisher's LSD K-ratio $t$-test was applied in order to determine whether differences between treatments were significant at $\alpha=0.05$.

\section{Results}

\subsection{Changes in the Effciacy of QoI Fungicides in the Control of Apple Scab}

The efficacy of kresoxim-methyl according to the apple scab level in the control untreated trees was tested from 2007 to 2017 in various orchards in Northern Israel. Figure 1 summarizes 
the changes in the efficacy of kresoxim-methyl against apple scab over time. The results show that kresoxim-methyl was effective until 2010, but its efficacy declined sharply to $43 \%$ since 2011, and continued to decline over the following years (Figure 1). It is important to note that two similar trials were conducted every year in these regions, from 2012 to 2014, but no scab was apparent in these experimental plots, due to lack of rain events in the spring. However, scab developed in 2015, 2016 and 2017, and the efficacy of kresoxim-methyl compared to the control was relatively low, with $27 \%, 54 \%$ and $23 \%$ efficacy, respectively (Figure 1).

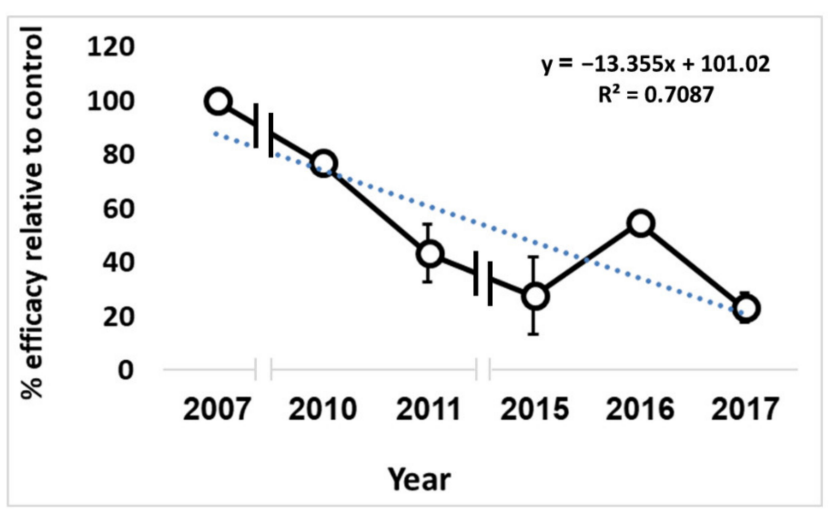

Figure 1. Changes in the efficacy of kresoxim-methyl in the control of apple scab in 9 different orchards in the Golan and Galilee regions during the last decade. Data represent the calculated efficacy against leaves or fruits scab, compared to control untreated trees in each orchard. The mean efficacy is presented in case of several experiments conducted in the same year (2011, 2015 and 2017). Bars represent the standard error of the mean.

3.2. Relationship between Average Rainfall ( $\mathrm{mm}$ ) in Season, Number of QoI Sprays per Season and Years until Occurrence of Resistance to QoI

Literature review revealed that in most countries, the high amount of rainfall $(255-555 \mathrm{~mm})$ and high number of QoI sprays applied during the most susceptible stages during the growing season were mostly related to the occurrence resistance to QoI within 3-5 years (Table 3). However, in the east Mediterranean climate of Israel, where the average rainfall was relatively low $(49 \mathrm{~mm})$, and only 2 QoI sprays were applied in each season, resistance only occurred after 14 years (Table 3). In Turkey, which is located between North-Central Europe and Israel with an average rainfall of $149 \mathrm{~mm}$, resistance appeared after 7 years of QoI usage. High correlation $\left(R^{2}=0.69\right)$ was observed between number of QoI sprays per season and years until resistance to QoI has been occurred (Figure 2).

Table 3. Comparison of years of QoI fungicides use until resistance appearance, number of QoI sprays per season and average rainfall $(\mathrm{mm})$ in the sensitive phenological stages, in different countries.

\begin{tabular}{|c|c|c|c|c|c|}
\hline State & $\begin{array}{c}\text { Year of QoI } \\
\text { Resistance Appeared }\end{array}$ & $\begin{array}{l}\text { Years of QoI Use } \\
\text { until Resistance }\end{array}$ & $\begin{array}{l}\text { Number of QoI } \\
\text { Sprays per Season }\end{array}$ & $\begin{array}{l}\text { Average Rainfall } \\
(\mathrm{mm}) \text { in Season }{ }^{1}\end{array}$ & Reference \\
\hline Southern Chile & 2003 & 5 & 3 & 433.00 & Sallato et al. [24] \\
\hline USA (Michigan) & 2001 & 4 & 4 & 334.60 & Köller et al. [15] \\
\hline USA (New York) & 2004 & 4 & 4 & 449.50 & $\begin{array}{l}\text { Turechek \& Köller, [25]; } \\
\text { Köller et al. [26] }\end{array}$ \\
\hline France (Rhône-Alpes) & 2002 & 4 & 4 & 305.00 & Fontaine et al. [13] \\
\hline Swiss & 1997 & 3 & $4-8$ & 381.00 & Küng Färber et al. [14] \\
\hline Serbia & 2002 & 5 & $3-7$ & 554.00 & Stević et al. [18] \\
\hline Northern Germany & 2000 & 3 & $4-9$ & 255.70 & Köller et al. [15] \\
\hline Northern Italy & 2002 & 5 & $3-7$ & 278.70 & Fiaccadori et al. [27] \\
\hline Turkey (Isparta) & 2005 & 7 & $3-4$ & 149.20 & Turan, [19]; Turan et al. [20] \\
\hline Northern Israel & 2011 & 14 & 2 & 49.10 & $\begin{array}{c}\text { Reuveni et al. [4] and } \\
\text { current study }\end{array}$ \\
\hline
\end{tabular}

${ }^{1}$ Average rainfall (mm) during April, May, June and July in Northern Hemisphere and October, November, December and January for Southern Hemisphere according to https:/ / www.weather-atlas.com (accessed on 6 September 2020). 


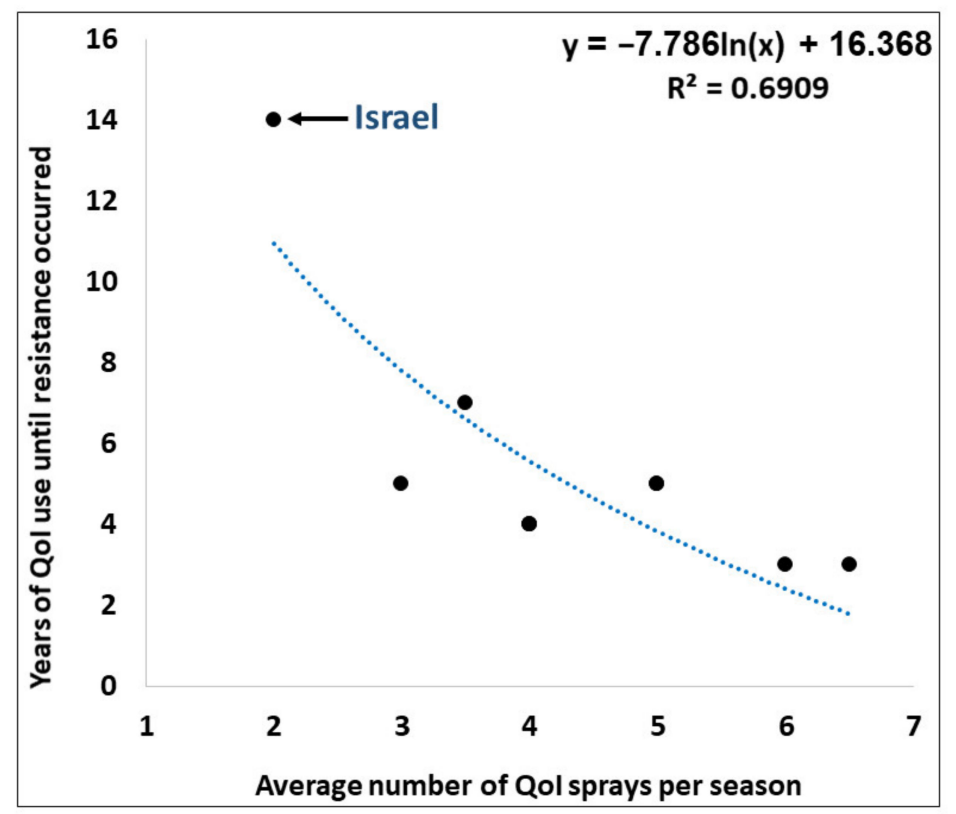

Figure 2. Correlation and logarithmic regression between number of QoI sprays per season and years until occurrence of resistance to QoI. Data points are derived from data on resistance of $V$. inaequalis to QoI from 10 countries/regions presented in Table 3. Israel is marked by an arrow. $\mathrm{R}^{2}$ and equation of the regression is presented.

\subsection{Field Trials to Examine the Efficacy of QoI Fungicides against Apple Scab}

The tank-mixture of kresoxim-methyl plus captan used to be one of the leading standards for control of apple scab in Northern Israel. The results of trial 1 conducted in 2010 showed that kresoxim-methyl plus captan significantly reduced the percentage of infected leaves and the percentage of infected fruits by $78 \%$ and $66 \%$, respectively. The prepacked mixture tebuconazole plus captan (Orpan) was more effective, with a $96 \%$ and $91 \%$ reduction in infected leaves and fruits, respectively (Figure 3). However, different results were obtained for the same treatments in trial 2 in 2011, where the disease level in trees treated with the tank mixture of kresoxim-methyl plus captan on fruits was not different from that of the untreated control and was only partially effective on leaves, with only $56 \%$ efficacy relative to the control (Figure 4). On the other hand, tebuconazole plus captan provided a high efficacy of 95 and $96 \%$ on both fruits and leaves, respectively, in spite of the high disease pressure according to the untreated control trees in this orchard (Figure 4). A similar trend was observed in two additional trials conducted in 2011, trial 3 and trial 4 . In both trials, kresoxim-methyl alone provided less than $50 \%$ efficacy relative to the control, while tebuconazole plus captan provided almost $90 \%$ efficacy relative to the control (Table 4). In 2015, in trial 5, trifloxystrobin reduced infected leaves by $42 \%$ compared to the control, while the prepacked mixture of pyraclostrobin plus boscalid (Bellis) provided $78 \%$ efficacy. Trifloxystrobin reduced the percentage of infected leaf area by only $53 \%$, compared to pyraclostrobin plus boscalid with a $93 \%$ efficacy (Figure 5 ). In 2016, in trial 6, kresoxim-methyl was partially effective, with a 55\% efficacy, compared to difenoconazole (Score) with 100\% efficacy (Figure 6). In 2017, in trial 7, the triazole cyproconazole (Atemi-Extra) significantly reduced disease incidence and severity on leaves by $78 \%$ and $92 \%$, respectively, while kresoxim-methyl was ineffective and provided an efficacy of $18 \%$ and $41 \%$, respectively, relative to the control (Figure 7 ). 


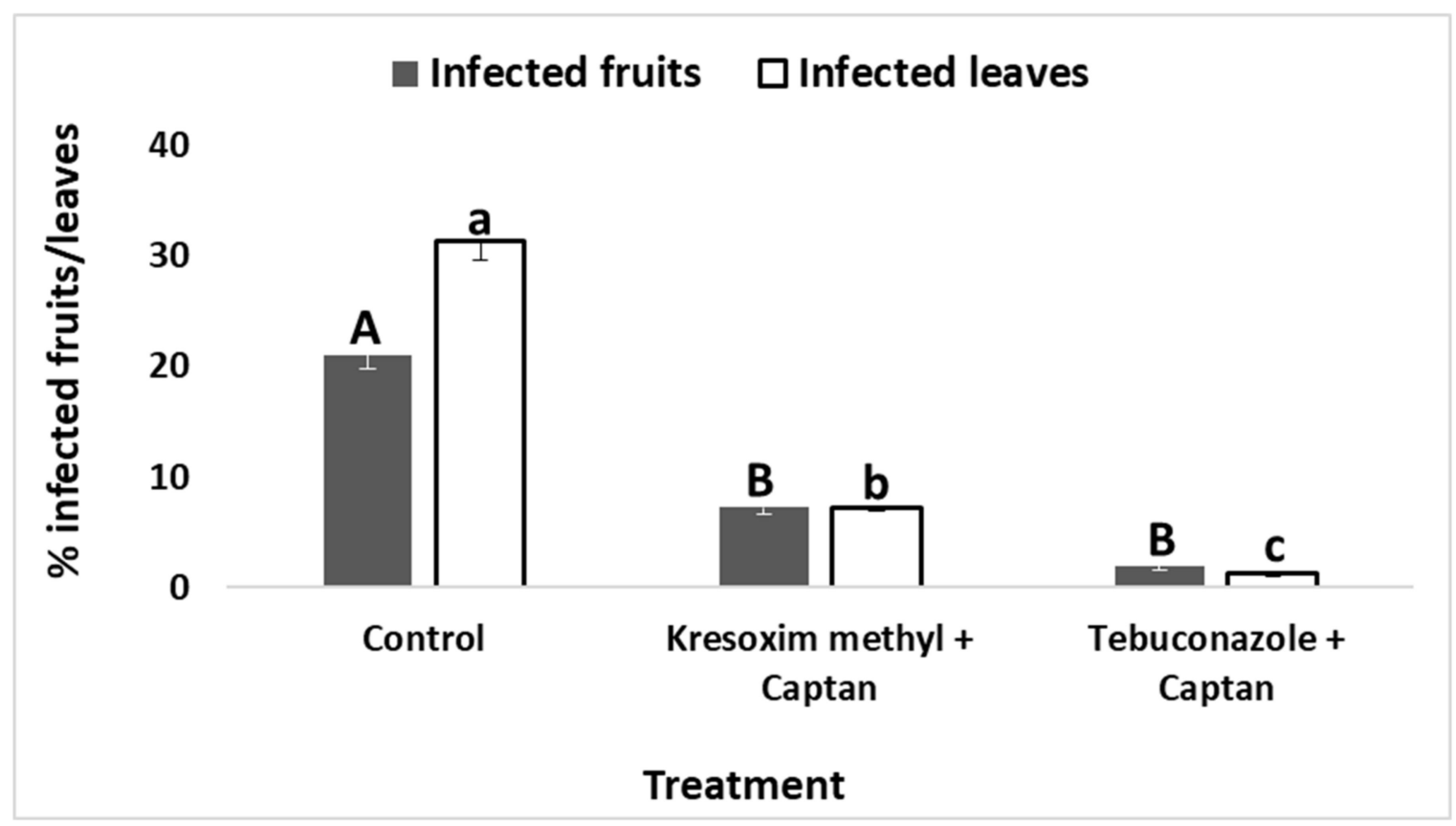

Figure 3. Activity of strobilurin and triazole fungicides in mixtures with captan on apple scab development in the Majdal Shams orchard 2010. The tank mixture of kresoxim-methyl at $0.015 \%(\mathrm{w} / \mathrm{v})+$ captan $0.25 \%(w / v)$ and the prepacked mixture Orpan at $0.3 \%$ (containing tebuconazole + captan) were tested. Bars represent the standard error of the mean. Different letters on the bars indicate significant differences $(p<0.05)$ according to Fisher's LSD K-ratio $t$-test.

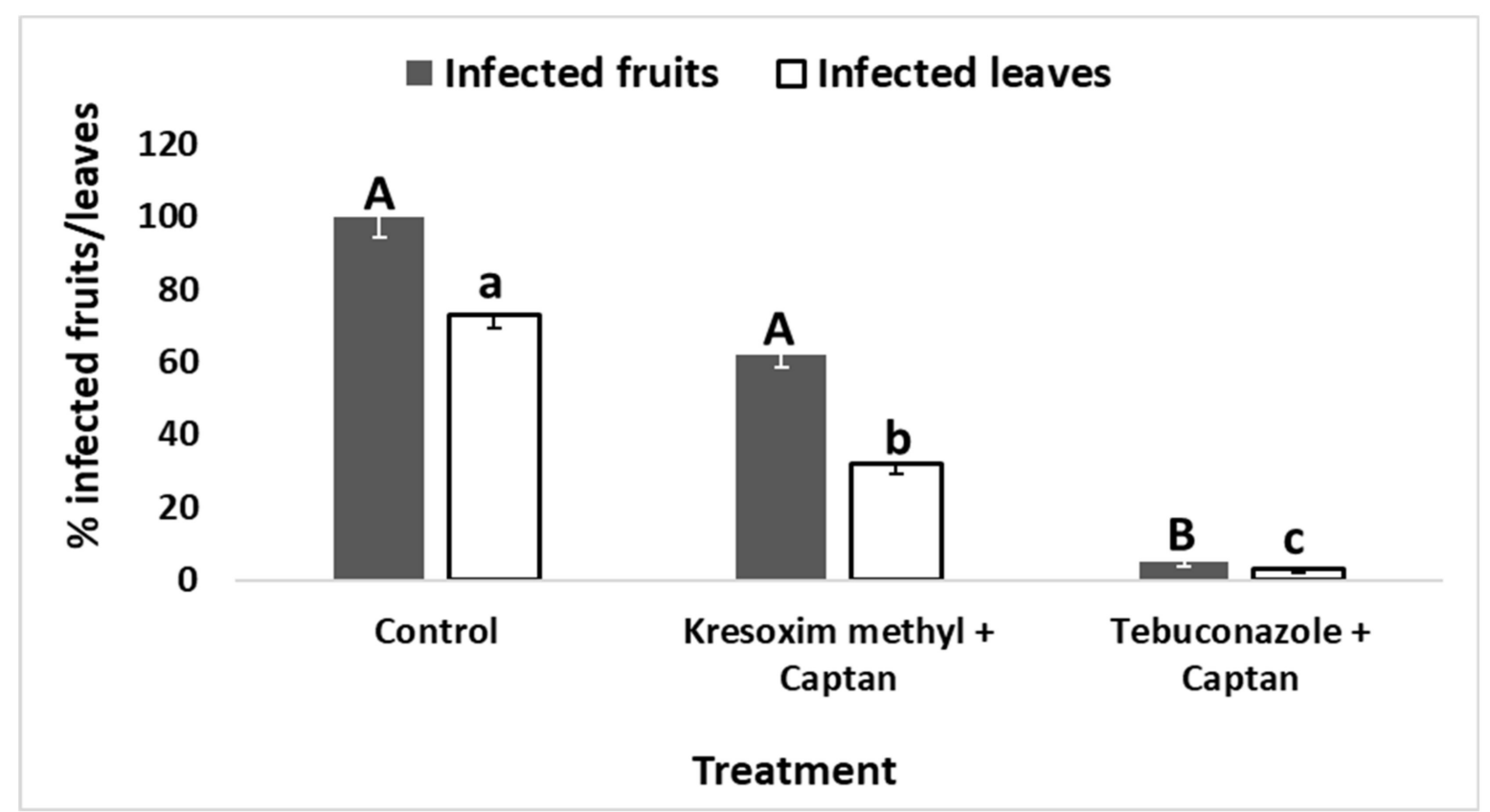

Figure 4. Activity of strobilurin and triazole fungicides in mixtures with captan on apple scab development in the Alonei Ha'bashan orchard in 2011. The tank mixture of kresoxim-methyl at $0.015 \%(w / v)+$ captan $0.25 \%(w / v)$, and the prepacked mixture Orpan at $0.3 \%$ (containing tebuconazole + captan) were tested. Bars represent the standard error of the mean. Different letters on the bars indicate significant differences $(p<0.05)$ according to Fisher's LSD K-ratio $t$-test. 
Table 4. Efficacy of Stroby (kresoxim methyl) and Orpan (tebuconazole + captan) in the control of apple scab in orchards in Northern Israel.

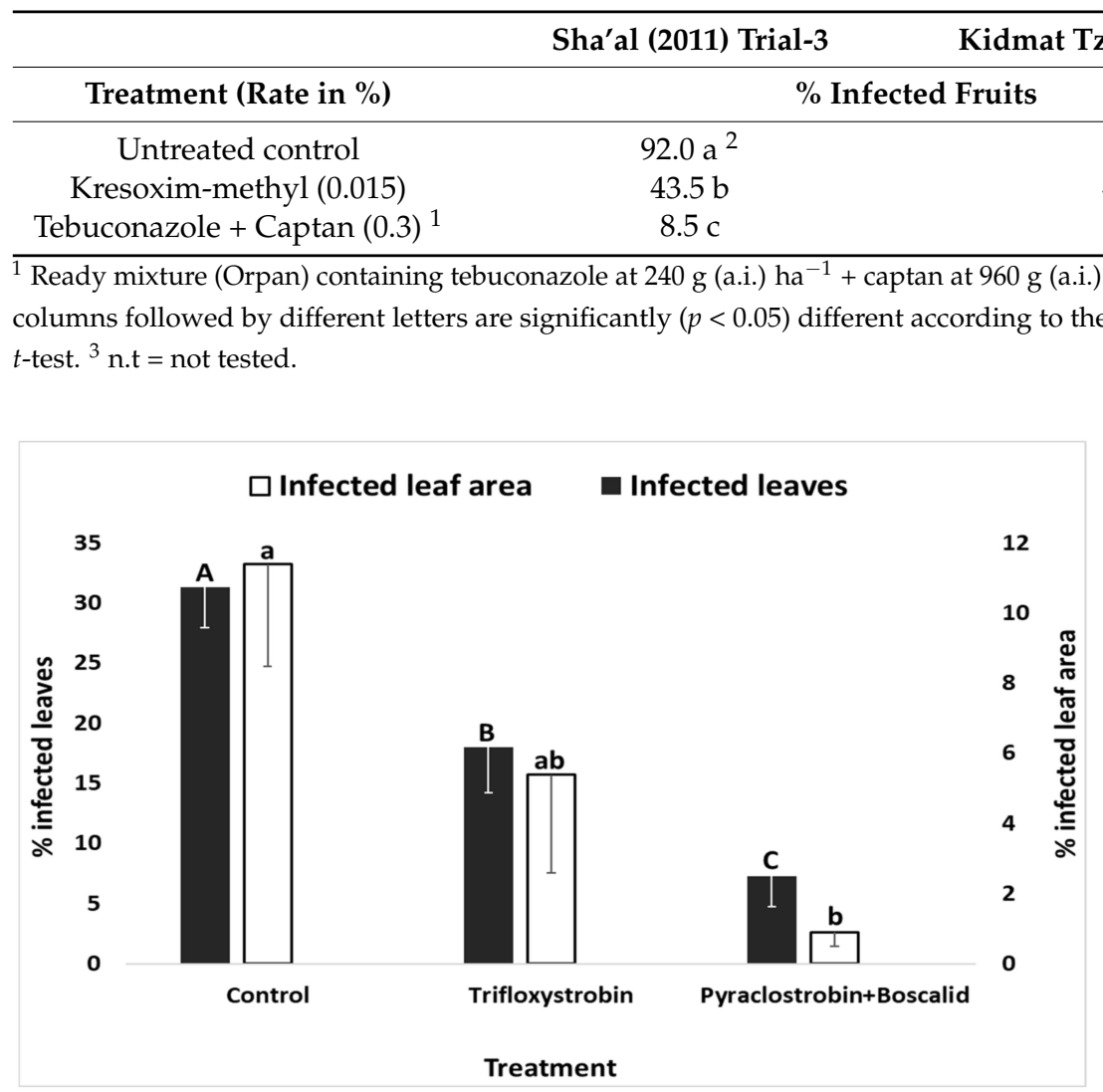

Figure 5. Activity of the strobilurin fungicide trifloxystrobin at $0.015 \%(w / v)$ and the prepacked mixture Bellis at $0.05 \%$ (containing pyraclostrobin + boscalid) on apple scab development in the Alonei Ha'bashan orchard in 2015. Bars represent the standard error of the mean. Different letters on the bars indicate significant differences $(p<0.05)$ according to Fisher's LSD K-ratio $t$-test.

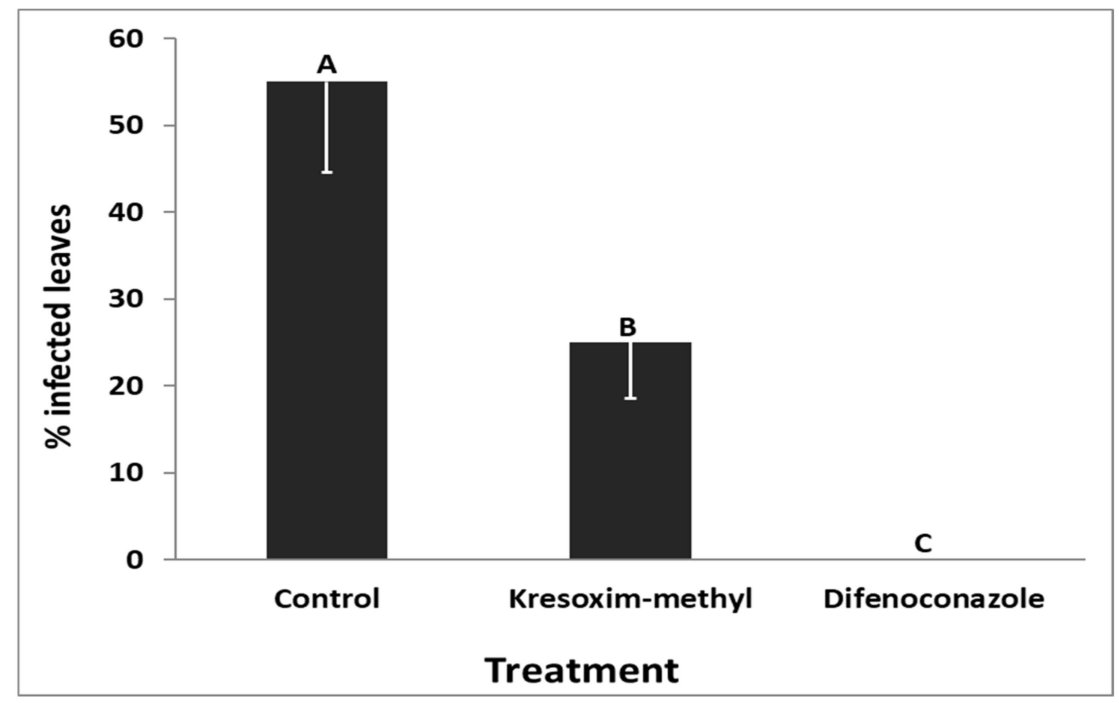

Figure 6. Efficacy of kresoxim-methyl at $0.015 \%(w / v)$ and difenoconazole at $0.02 \%(v / v)$ against apple scab in field grown Odem apple trees, Yesud HaMa'ala (Upper Galilee), 2016. Bars represent the standard error of the mean. Different letters on the bars indicate significant differences $(p<0.05)$ according to Fisher's LSD K-ratio $t$-test. 


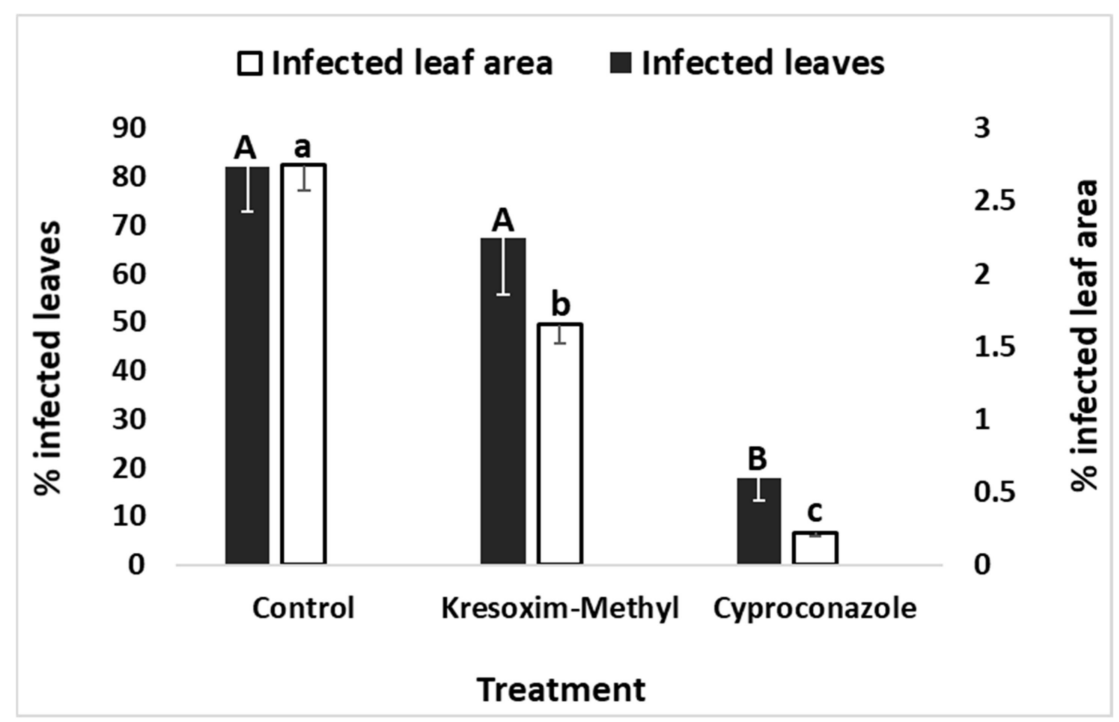

Figure 7. Efficacy of kresoxim-methyl at $0.015 \%(w / v)$ and cyproconazole at $0.03 \%(v / v)$ against apple scab in field grown Anna trees, Kadesh (Upper Galilee), 2017. Bars represent the standard error of the mean. Different letters on the bars indicate significant differences $(p<0.05)$ according to Fisher's LSD K-ratio $t$-test.

\subsection{In Vitro Inhibition of Mycelial Growth of V. inaequalis}

The activity of kresoxim-methyl and difenoconazole against ten $V$. inaequalis isolates, representing the nine orchards from which isolates were collected, was tested. The results showed that, with the exception of one sensitive isolate (V.i-Bq-No-l-d) collected from Buq'ata in the Northern Golan from an abandoned orchard left uncultivated in recent years, all other isolates were resistant or moderately resistant to kresoxim-methyl (Table 5). All isolates were sensitive to difenoconazole, which effectively inhibited mycelial development of the tested isolates (Table 5).

Table 5. Sensitivity of mycelia of ten Venturia inaequalis isolates to kresoxim-methyl and difenoconazole.

\begin{tabular}{|c|c|c|c|c|}
\hline \multicolumn{5}{|c|}{ \% Efficacy Relative to Control ${ }^{1}$} \\
\hline Isolate $^{2}$ & kresoxim-Methyl & Difenoconazole & $\begin{array}{c}\text { Degree of Sensitivity to } \\
\text { Kresoxim-Methyl }{ }^{3}\end{array}$ & $\begin{array}{c}\text { Degree of Sensitivity to } \\
\text { Difenoconazole }\end{array}$ \\
\hline V.i-Mat-l-d & 0 & 100 & $\mathrm{R}$ & $S$ \\
\hline V.i-Mat-l-u & 0 & 100 & $\mathrm{R}$ & $S$ \\
\hline V.i-Bq-Gs-l-d & 3 & 100 & $\mathrm{R}$ & $S$ \\
\hline V.i-Ym-f & 8.2 & 84 & $\mathrm{R}$ & $S$ \\
\hline V.i-Hv-l-u & 17.3 & 100 & $\mathrm{R}$ & $S$ \\
\hline V.i-ER-f & 26 & 100 & $\mathrm{R}$ & $S$ \\
\hline V.i-Al-l-d & 28.7 & 100 & $\mathrm{R}$ & $S$ \\
\hline V.i-Bq-Gs-f & 33.3 & 100 & M & $S$ \\
\hline V.i-Ym-l-d & 55.3 & 100 & $\mathrm{M}$ & $S$ \\
\hline V.i-Bq-No-l-d & 77 & 78 & S & S \\
\hline
\end{tabular}

${ }^{1}$ Efficacy of kresoxim-methyl at $75 \mu \mathrm{g} \mathrm{mL}{ }^{-1}$ and difenoconazole at $50 \mu \mathrm{g} \mathrm{mL} \mathrm{m}^{-1}$ against $V$. inaequalis mycelial growth at 27 days after inoculation. ${ }^{2}$ Information on the tested isolates is specified in Table S1. ${ }^{3} \mathrm{R}=$ resistance ( $0-30 \%$ efficacy) $\mathrm{M}=$ moderate ( $30-75 \%$ efficacy), $\mathrm{S}$ $=$ susceptible $(>75 \%$ efficacy $)$.

The activity of kresoxim-methyl, trifloxystrobin, captan and difenoconazole, each at various concentrations, was examined against mycelial growth of one $V$. inaequalis isolate, collected from highly infected orchard in Alonei Ha'bashan in 2014. The isolate was found to be insensitive to both kresoxim-methyland and trifloxystrobin at all concentrations used, including the recommended concentration used in the field $\left(75 \mu \mathrm{g} \mathrm{mL}{ }^{-1}\right.$ a.i.), presenting an $\mathrm{EC}_{50}$ greater than $75 \mathrm{ppm}$ (Table 6). However, with the exception of a relatively low 
concentration of $12 \mathrm{ppm}$ a.i. of captan, the isolate was found to be sensitive to both difenoconazole and captan at all other concentrations used (Table 6). A further experiment was undertaken to show the activity of various concentrations of kresoxim-methyl against mycelial growth of $V$. inaequalis of susceptible and resistant isolates. While $75 \mu \mathrm{g} \mathrm{mL}^{-1}$ a.i. of kresoxim-methyl were needed to inhibit the mycelial growth of the susceptible isolate, even $7500 \mu \mathrm{g} \mathrm{mL}^{-1}$ a.i. of this fungicide (100-fold greater than the recommended dose in orchard application) did not provide any inhibition of mycelial growth of the two resistant isolates V.i-Bq-Mn-l-d and V.i-Sh-f (Figure 8). The concentration of $75 \mu \mathrm{g} \mathrm{mL}^{-1}$ a.i. showed small inhibition effect on isolate V.i-YM-f, increasing in the high concentrations of 750 and $7500 \mu \mathrm{g} \mathrm{mL}^{-1}$ a.i. (Figure 8). This result supports the previous in vitro test showing $8.2 \%$ efficacy against this isolate at $75 \mu \mathrm{g} \mathrm{mL}^{-1}$ a.i. (Table 5).

Table 6. Efficacy values $\mathrm{EC}_{50}\left(\mu \mathrm{g} \mathrm{mL}{ }^{-1}\right.$, ai) of fungicides and fungicide mixtures against mycelial growth of $V$. inaequalis isolate V.i-AL-f.

\begin{tabular}{|c|c|c|c|}
\hline Treatment (Maximal Concentration) ${ }^{1}$ & Colony Diameter (mm) at Maximal Concentration & $\mathrm{EC}_{50}{ }^{2}$ & $\mathbf{R}^{2}$ \\
\hline Control & $23.08 \mathrm{a}^{3}$ & - & - \\
\hline Kresoxim-methyl (75) & $20.42 \mathrm{~b}$ & $>75$ & 0.926 \\
\hline Trifloxystrobin (75) & $13.08 \mathrm{c}$ & $>75$ & 0.886 \\
\hline Difenoconazole (50) & $4.08 \mathrm{~d}$ & 0.124 & 0.866 \\
\hline Captan $(1200)$ & $1.00 \mathrm{e}$ & 64.8 & 0.829 \\
\hline Captan + tebuconazole ${ }^{4}(1200)$ & $1.00 \mathrm{e}$ & 44.3 & 0.879 \\
\hline Boscalid + pyraclostrobin ${ }^{5}(190)$ & $1.00 \mathrm{e}$ & 1.66 & 0.878 \\
\hline Cyprodinil + tebuconazole ${ }^{6}(312.5)$ & $1.00 \mathrm{e}$ & 0.14 & 0.930 \\
\hline
\end{tabular}

${ }^{1}$ Maximal concentrations tested of fungicides and fungicide mixtures given at $\mu \mathrm{g} \mathrm{mL}{ }^{-1}$, ai. ${ }^{2}$ Values of $\mathrm{EC}_{50}$ were calculated with probit analysis (SPSS). ${ }^{3}$ Means within the colony diameter column followed by different letters are significantly $(p<0.05)$ different according to the Fisher's LSD K-ratio $t$-test. ${ }^{4}$ Orpan, a prepacked mixture containing captan $\left(320 \mathrm{~g} \mathrm{~L}^{-1}\right.$, a.i. $)+$ tebuconazole $\left(80 \mathrm{~g} \mathrm{~L}^{-1} \text {, a.i. }\right)^{5}$ Bellis, a prepacked mixture containing boscalid $\left(252 \mathrm{~g} \mathrm{~L}^{-1}\right.$, a.i. $)+$ pyraclostrobin $\left(128 \mathrm{~g} \mathrm{~L}^{-1}\right.$, a.i.) ${ }^{6}$ Benelus, a prepacked mixture containing cyprodinil $\left(187.5 \mathrm{~g} \mathrm{~L}^{-1}\right.$, a.i. $)+$ tebuconazole $\left(125 \mathrm{~g} \mathrm{~L}^{-1}\right.$, a.i.)

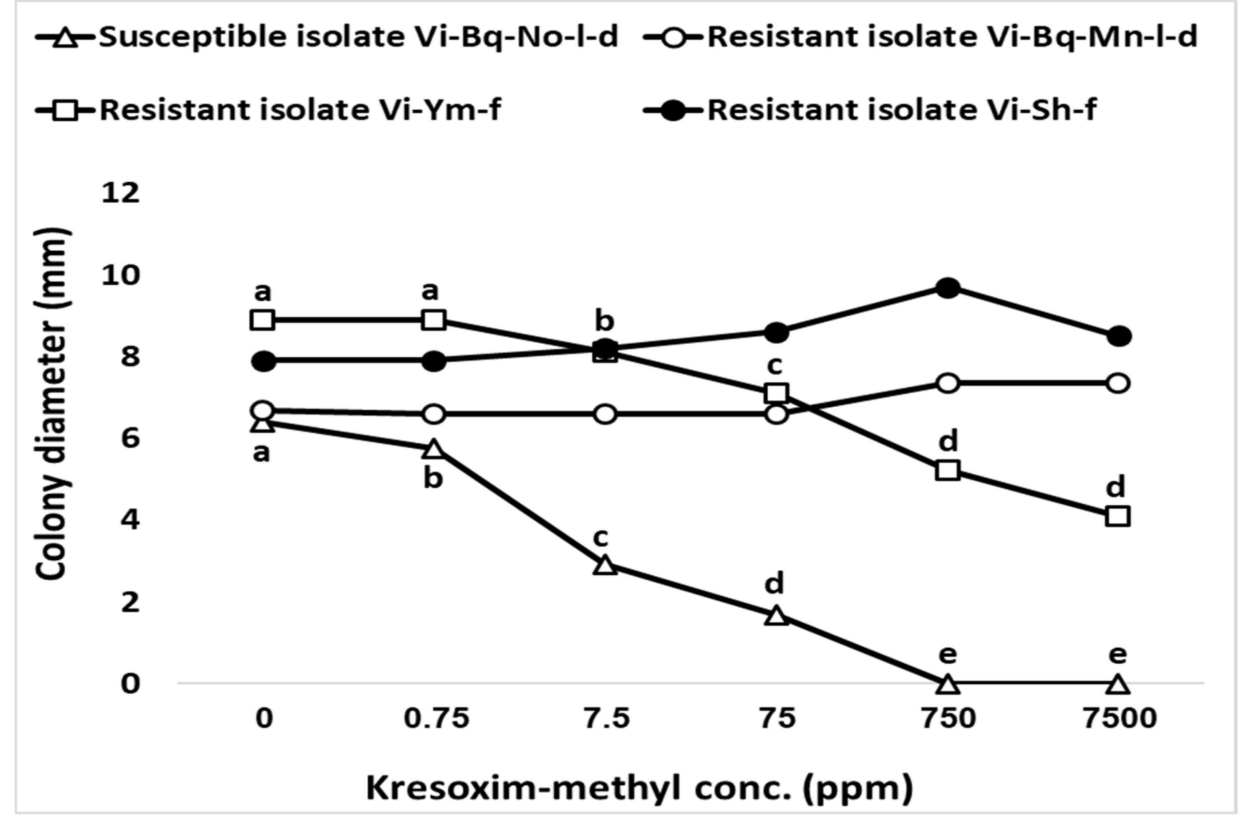

Figure 8. Activity of different concentrations of kresoxim-methyl on mycelial growth of susceptible (V.i-Bq-No-l-d) and three resistant (V.i-Bq-Mn-l-d, Vi-Ym-f and Vi-Sh-f) isolates. Colony diameters were recorded on day 14 post-inoculation. Different letters for isolates V.i-Bq-No-l-d and Vi-Ym-f indicate significant differences $(p<0.05)$ according to Fisher's LSD K-ratio $t$-test. 


\subsection{PCR-Based Detection of the G143A Mutation in V. inaequalis}

Of the $28 \mathrm{~V}$. inaequalis isolates tested from the Golan and Upper Galilee regions, only a single isolate (V.i-Bq-No-l-d), from a deserted orchard in the village of Buq'ata, revealed absence of amplification of a $433 \mathrm{bp}$ fragment and was therefore considered QoI-sensitive. All other 27 isolates presented the $433 \mathrm{bp}$ fragment and were therefore considered QoI-resistant (Figure S2). All isolates presented the $238 \mathrm{bp}$ fragment, confirming that these are isolates of $V$. inaequalis and that the absence of amplification of a $433 \mathrm{bp}$ fragment did not result from PCR inhibition (Figure S2). These results match the in vitro sensitivity tests (Table 5).

\subsection{Molecular Detection of the G143A CYTB Gene Mutation by Direct Sequencing}

In order to determine the presence of the G143A mutation in each of the 28 isolates and to screen for additional SNPs in the CYTB gene, direct sequencing of a $938 \mathrm{bp}$ DNA fragment that included codon 143 was conducted. The sequence results of the 28 Israeli isolates showed that no additional mutation in the CYTB gene were present in these isolates. Correlation of the results to the PCR-based detection method showed that sequences of all 27 isolates were identical (represented by isolate V.i-ER-f, Accession No. MT267359) and contained the G143A mutation (Guanine (G) instead of Cytosine (C)) in position 5437 (according to AF004559 reference isolate) and were therefore confirmed to be QoI-resistant (Table 7). Only isolate V.i-Bq-No-l-d (Accession No. MT267360) presented Cytosine (C) at position 5437, confirming its sensitivity to Qol. Screening of all 28 sequence chromatograms showed no evidence of heteroplasmy in any of the isolates.

Table 7. Partial sequences of cytochrome b (CYTB) gene region representing isolates sensitive and resistant to QoI fungicides.

\begin{tabular}{lc}
\hline Isolate $(\mathbf{N})^{\mathbf{1}}$ & Sequence $^{\mathbf{2}}$ \\
\hline V.i-Bq-No-l-d (1) & ATG AGC CTA TGG GCT GCA ACT GTC ATC ${ }^{4}$ \\
\hline V.i-ER-f (27) & ATG AGC CTA TGG GGT GCA ACT GTC ATC \\
\hline AF004559 ${ }^{3}$ & ATG AGC CTA TGG GGT GCA ACT GTC ATC \\
\hline${ }^{1} N=$ Number of isolates sharing an identical nucleotides sequence. ${ }^{2}$ Partial sequence presenting the G143A \\
mutation: G (Guanine) instead of C (Cytosine) in position 5437 (according to AF004559 reference isolate) in bold. \\
${ }^{3}$ Reference resistant isolate published by Zheng and Koller, [28]. ${ }^{4}$ Shaded and unshaded areas distinguishes the \\
amino acids codons.
\end{tabular}

\subsection{Use of Fungicidal Mixtures for Improving Efficacy}

Fungicidal mixtures were tested for their efficacy against $V$. inaequalis in the laboratory and against apple scab in the field. In laboratory the QoI fungicides kresoxim mathyl and tifloxystrobin were ineffective and presented $\mathrm{EC}_{50}$ of $>75 \mu \mathrm{g} \mathrm{mL}^{-1}$ (Table 6). The prepacked mixture containing tebuconazole plus captan (Orpan) was partially effective in laboratory against mycelial growth, with an $\mathrm{EC}_{50}$ of $44.3 \mu \mathrm{g} \mathrm{mL}{ }^{-1}$, but more effective than captan alone with $\mathrm{EC}_{50}$ of $64.8 \mu \mathrm{g} \mathrm{mL}^{-1}$ (Table 6), whereas it was highly effective in the field in controlling apple scab on both fruits and leaves, with only $0-3 \%$ infected fruits and $0-5.5 \%$ infected leaves in both trials (Figure 9 and Table 8). Interestingly, the prepacked mixture containing the QoI fungicide trifloxystrobin with boscalid (Discovery) also reduced the number of infected fruits by $81 \%$ and leaves by $63 \%$ compared to control untreated trees but did not completely inhibit disease development as shown with tebuconazole plus captan (Figure 9). Kresoxim-methyl alone was ineffective and provided similar results to the untreated control (Figure 9). The recently registered prepacked mixtures cyprodinil plus tebuconazole (Benelus) and pyraclostrobin plus boscalid (Bellis) were effective in both laboratory experiments with an $\mathrm{EC}_{50}$ of 0.14 and $1.66 \mu \mathrm{g} \mathrm{mL}^{-1}$, respectively, and in field trials (Tables 6 and 8 and Figure 5). Moreover, the addition of captan in a tank mixture to either thiophanate-methyl, or the prepacked mixture of fluopyram plus tebuconazole (LunaExperience), improved their protection in the orchard and provided $90 \%$ and $86 \%$ efficacy, on leaves and $75 \%$ and $99 \%$, efficacy on fruits, respectively, compared to each fungicide 
without captan (Table 8). The addition of captan in a tank mixture to difenoconazole improved its efficacy on fruits by $67 \%$, but not on leaves. All mixtures provided excellent scab control on both fruits and leaves (Table 8).

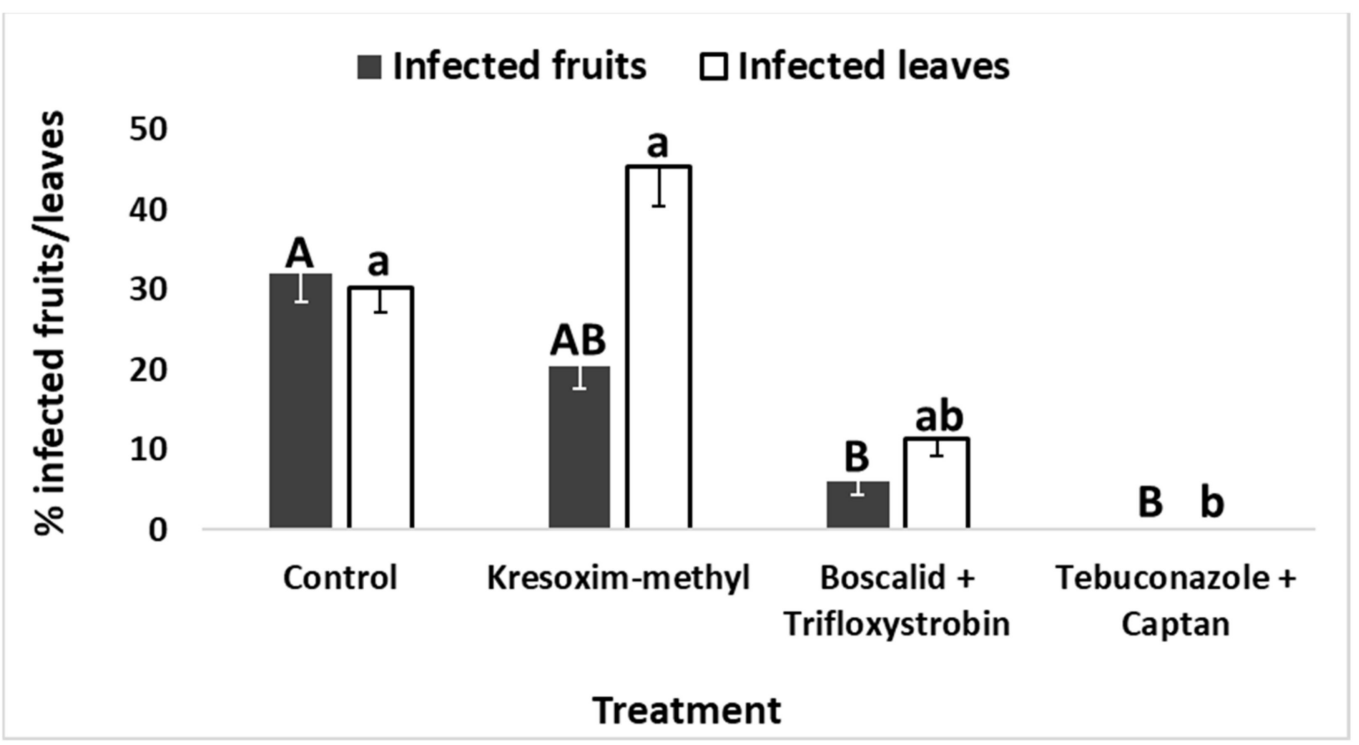

Figure 9. Efficacy of prepacked fungicidal mixtures compared to kresoxim-metyl at $0.015 \%(\mathrm{w} / \mathrm{v})$ alone in controlling apple scab. Buq'ata, 2015. Prepacked mixture Discovery at $0.075 \%(v / v)$ (containing boscalid + trifloxystrobin) and prepacked mixture Orpan at $0.3 \%(\mathrm{v} / \mathrm{v})$ (containing tebuconazole + captan) were used. Bars represent the standard error of the mean. Different letters on the bars indicate significant differences $(p<0.05)$ according to Fisher's LSD K-ratio $t$-test.

Table 8. Efficacy of various fungicides and their mixtures in controlling apple scab on Starking Delicious apple leaves and fruits in the orchard, 2017.

\begin{tabular}{|c|c|c|}
\hline Treatment (Concentration in \%) ${ }^{1}$ & $\%$ Infected Leaves & $\%$ Infected Fruits \\
\hline Control & $69.5 \mathrm{a}$ & $28.5 \mathrm{a}$ \\
\hline Thiophanate-methyl (0.05) & $44 \mathrm{~b}$ & $10 \mathrm{~b}$ \\
\hline Thiophanate-methyl $(0.05)+$ captan $(0.25)$ & $4 \mathrm{c}$ & $2.5 \mathrm{bc}$ \\
\hline$(\text { fluopyram }+ \text { tebuconazole })^{2}(0.035)$ & $7 \mathrm{c}$ & $6 \mathrm{bc}$ \\
\hline (fluopyram + tebuconazole) $(0.035)+\operatorname{captan}^{3}(0.25)$ & $1.5 \mathrm{c}$ & $0.01 \mathrm{c}$ \\
\hline Difenoconazole $(0.02)$ & $4 \mathrm{c}$ & $3 \mathrm{bc}$ \\
\hline Difenoconazole $(0.02)+$ captan $(0.25)$ & $7 \mathrm{c}$ & $1 \mathrm{c}$ \\
\hline (cyprodinil + tebuconazole) ${ }^{4}(0.1)$ & $2.2 \mathrm{c}$ & $7 \mathrm{bc}$ \\
\hline$(\text { captan }+ \text { tebuconazole })^{5}(0.3)$ & $5.5 \mathrm{c}$ & $2.67 \mathrm{bc}$ \\
\hline
\end{tabular}

${ }^{1}$ Three foliar sprays of each fungicide or mixture were applied on March 28 (Green Tip (BBCH-09), April 12 and May 16, according to rain events. Evaluation date was June $11 .{ }^{2}$ Luna Experience, a prepacked mixture containing fluopyram + tebuconazole. ${ }^{3}$ A tank mixture of Luna Experience + captan. ${ }^{4}$ Benelus, a prepacked mixture containing cyprodinil + tebuconazole. ${ }^{5}$ Orpan, a prepacked mixture containing captan + tebuconazole. ${ }^{6}$ Means within columns followed by different letters are significantly different $(p<0.05$, according to Fisher's LSD K-ratio $t$-test)

\section{Discussion}

This study was conducted in order to determine whether $V$. inaequalis has acquired resistance to QoI fungicides in a hot and dry Eastern Mediterranean climate region with unfavorable climatic conditions for the pathogen development, in a representative region of Northern Israel. A combination of in vitro, molecular methodologies and field trials was used in this study to demonstrate, for the first time, that resistance to QoI fungicides is evident in this region.

Indeed, a clear reduction in QoI-based fungicides efficacy against $V$. inaequalis is shown in Israeli apple orchards since 2011. It seems that until 2010, the mixture of kresoxim-methyl plus captan (a common standard used by the growers) was still effective in controlling scab 
on both leaves and fruits. The significant reduction was shown in the 2011 trials, in which kresoxim-methyl did not provide satisfactory control of scab on leaves and fruits. Similar results were obtained in 2015, 2016 and 2017, where kresoxim-methyl or trifloxystrobin, each applied alone, were ineffective and exhibited a much lower efficacy than that obtained by using DMI fungicides or fungicidal mixtures. The percent efficacy of kresoxim-methyl over the years is summarized in Figure 1. The result emphasizes this trend and suggests the occurrence of resistant strains in the field and insufficient control by the QoI-based fungicides since 2011.

The life cycle of $V$. inaequalis is comprised of one sexual and multiple asexual reproductions annually. This causes significant variations in the fungus population. Annual sexual reproduction leads to recombination and high variation in fungal genome and changes in the population's genetic structure. Genetic recombination occurs during sexual reproduction, while selection for specific fungicides may lead to the emergence of resistant strains [29]. The resistance to QoI is induced by a single mutation (G143A) in the CYTB gene (cytochrome b) $[13,23]$. A single resistance gene conferring a very high level of resistance to a particular fungicide will not allow disease control at any feasible dose of that fungicide. This was supported by the in vitro experiments exhibiting isolates that grew on $7500 \mu \mathrm{g} \mathrm{mL}^{-1}$ a.i, a concentration 100-fold higher than the recommended dose in the orchard. Complete lack of disease control will lead to a fast selection of highly resistant subpopulations [15]. Although QoI resistance is considered qualitative (or complete resistance), the fact that in the in vitro tests isolates displayed a range of insensitivity response to kresoxim-methyl (Table 5, Figure 8) may support the reports on quantitative (polygenic or partial) resistance response to QoI fungicides in $V$. inaequalis [15]. The molecular basis of quantitative resistance to QoI fungicides in $V$. inaequalis is poorly understood, but it may open new interesting questions about this mechanism, particularly in the unique condition of the Israeli weather.

The in vitro and field findings were supported by the genetic study showing $97 \%$ of the isolates with the G143A mutation. However, while in North and Central Europe and North America resistance occurred after 3-5 years of QoI usage, in Israel, resistance to QoI fungicides and mainly kresoxim-methyl occurred only after 14 years of use since the first introduction of QoI's in Israel in 1997 (Table 3). Unlike under conditions in Europe and North America, the mild winter and limited rain events during the growing period in Eastern Mediterranean climatic conditions, as in Israel, with a reduced number of fungicide applications (Table 3, Figure 2), most likely led to reduction in the probability and delay in resistance development. The high logarithmic correlation between the number of QoI sprays and the years for resistance development suggests that in a reduced number of sprays (2-3) like in Israel, one additional spray might have more significant effect on resistance development, than in a higher number of sprays (5-6). This study also shows that resistance may occur and persist in the orchards even under unfavorable disease conditions. It is also assumed that the warm and dry Mediterranean climatic conditions cause lower rates of sexual reproduction, which may also reduce the probability of genetic recombination $[1,30]$. This was supported by Boehm et al. [21] reporting that in temperate apple growing regions, the primary spring inoculum of $V$. inaequalis is derived from overwintered pseudothecia. In contrast, in the apple orchards at lower elevations in Israel, which rarely experienced low winter temperatures, the pathogen does not reproduce sexually and is instead composed of clonal lineages.

The scope of resistance in Israel may therefore be widespread, and the effectiveness of any other strobilurin-based fungicide against apple scab disease is currently in doubt. It was therefore recommended to temporarily reduce or avoid QoIs application until the population reverts to being genetically sensitive to these treatments [4]. This may drastically limit the arsenal of fungicides available to growers for combating apple scab and poses a significant challenge for apple growers to successfully manage $V$. inaequalis. QoI fungicides have been removed from management recommendations for control of $V$. inaequalis in other regions as well [31,32]. 
Based on that, growers must revert to using either multisite fungicides alone (mostly dithianon, mancozeb and captan) or mixtures with other systemic fungicides of different groups, in order to avoid a continuous shift of $V$. inaequalis populations toward resistance. Captan is regarded as a low-risk fungicide with no evidence of resistance [33]. Adding captan, either as part of a prepacked mixture (with tebuconazole = Orpan) or in a tank mixture (with Luna-experience), or with difenoconazole or thiophanate-methyl provided better disease control (Table 8 and Figure 9). It also enabled lowering the proportion of the at-risk fungicide and reducing the selection pressure for fungicide resistance, without compromising effective disease control [34,35].

Fungicides are also combined in mixtures to expand the spectrum of their activity, to prolong persistence, and to improve disease control by exploiting synergistic interactions between their components [34,36]. Fungicides in mixtures may involve antifungal compounds of differing natures and sources, differing or identical modes of action, or differing formulations [36]. This approach was successfully demonstrated against Alternaria fruit rot [37] and moldy core [38] diseases in apple. This approach is considered an important tactic in resistance management. In the present study, the high efficacy of several fungicidal mixtures, such as Orpan, Benelus, Bellis and Luna-Experience against $V$. inaequalis was demonstrated in vitro and in orchards (Tables 6 and 8, and Figure 9).

In summary, it is probable that eastern Mediterranean climate in Israel and reduced usage of QoI fungicides delayed the occurrence of $V$. inaequalis resistance to QoI fungicides. Nevertheless, resistance is currently widespread, and the use of fungicide mixtures as an approach in apple scab management should be an important component of the toolbox to combat apple scab, including populations resistant to this group of fungicides. This, along with the use of scab-tolerant or scab-resistant cultivars, and together with other cultural practices, such as removal of fallen leaves to eliminate sources of primary inoculum, should provide an adequate disease control.

\section{Conclusions}

This paper describes the development of resistance of Venturia inaequalis to QoI fungicides in Israel. Unlike other regions in the world, in which resistance of $V$. inaequalis to QoI fungicides was observed within 3-5 years of use, in Israel it only occurred after 14 years of use. This is probably due to unfavorable climate conditions for the pathogen, which led to reduced number of sprays. Resistance is demonstrated in the orchard, in in vitro and in molecular-based study, which forced the growers to avoid using QoIs against apple scab. Applications of tank mixtures or prepacked fungicidal mixtures improved efficacy and can be used as a strategic approach in fungicide resistance management.

Supplementary Materials: The following are available online at https:/ /www.mdpi.com/2073-439 5/11/2/396/s1. Table S1: Isolates of Venturia inaequalis from apple orchards that were used in this study. Isolates were collected from infected apple fruits and leaves of cv. Red Delicious Starking in nine different orchards in Northern Israel (The Golan, Upper Galilee and Hula Valley), the main growing region in Israel. Figure S1: Map of Israel (right bottom corner) with the current study area highlighted in blue. Magnification of the Galilee and Golan regions with the experimental orchards (yellow triangle) and sites of isolates collection (red circles). Figure S2: PCR of the 24 out of 28 apple scab isolates collected. All isolates show a band at $238 \mathrm{bp}$, confirming that these are isolates of $V$. inaequalis. Most isolates, except number 3 (marked with a white arrow), show a band at $433 \mathrm{bp}$, confirming their resistance to strobilurins and the sensitivity of isolate 3 to QoI.

Author Contributions: M.R. supervision; M.R., L.G., K.L. and O.F. conceived and designed the experiments; L.G., A.F. and K.L. performed the experiments and analyzed the data; M.R., L.G. and O.F. wrote and revised manuscript. All authors have read and agreed to the published version of the manuscript.

Funding: This research was supported by the Ministry of Science and Technology, State of Israel, research grant No. 38427. 
Data Availability Statement: Accession Numbers MT267359 and MT267360 can be found in National Center for Biotechnology Information (NCBI, National Library of Medicine, USA, http:/ / www.ncbi. nlm.nih.gov (accessed on 6 September 2020)).

Acknowledgments: The authors would like to thank Ezra Shabi, David Burg, Aviad Shachar and the orchard crews in the Golan and Galilee regions for their valuable assistance and Adama Agricultural Solutions Ltd., Israel, and Tapazol for their cooperation in the field trials. This work was supported by the Ministry of Science and Technology, State of Israel, research grant No. 38427.

Conflicts of Interest: The authors have no conflicts of interest to declare.

\section{References}

1. MacHardy, W.E. Apple Scab: Biology, Epidemiology, and Management; APS Press: St. Paul, MN, USA, 1996.

2. Biggs, A.R.; Stensvand, A. Apple scab. In Compendium of Apple and Pear Diseases and Pests; Sutton, T.B., Aldwinckle, H.S., Agnello, A.M., Walgenbach, J.F., Eds.; APS: St. Paul, MN, USA, 2014.

3. Alaniz, S.; Leoni, C.; Bentancur, O.; Mondino, P. Elimination of summer fungicide sprays for apple scab (Venturia inaequalis) management in Uruguay. Sci. Hort. 2014, 165, 331-335. [CrossRef]

4. Reuveni, M.; Levy, K.; Gur, L.; Frenkel, O.; Burg, D.; Ovadia, S.; Farber, A.; Shahar, A. Occurrence of Venturia inaequalis resistance to QoI fungicides in Israel apple orchards. Phytoparasitica 2016, 44, 277. (In Abstract)

5. Shabi, E.; Roberts, A.L.; Crute, I.R.; Boehm, E.W.A.; Oppenheim, D.; Elisha, S.; Katan, T. Variation in sensitivity of Venturia inaequalis to DMI and strobilurin fungicides. Phytoparasitica 1997, 25, 260-261. (In Abstract)

6. Chatzidimopoulos, M.; Lioliopoulou, F.; Sotiropoulos, T.; Vellios, E. Efficient control of apple scab with targeted spray applications. Agronomy 2020, 10, 217. [CrossRef]

7. Bartlett, D.W.; Clough, J.M.; Godwin, J.R.; Hall, A.A.; Hamer, M.; Parr-Dobrzanski, B. The strobilurin fungicides. Pest Manag. Sci. 2002, 58, 649-662. [CrossRef] [PubMed]

8. Ishii, H.; Fraaije, B.A.; Sugiyama, T.; Noguchi, K.; Nishimura, K.; Takeda, T.; Amano, T.; Hollomon, D.W. Occurrence and molecular characterization of strobilurin resistance in cucumber powdery mildew and downy mildew. Phytopathology 2001, 91, 1166-1171. [CrossRef]

9. Jiang, J.; Ding, L.; Michailides, T.J.; Li, H.; Ma, Z. Molecular characterization of field azoxystrobin-resistant isolates of Botrytis cinerea. Pestic Biochem. Physiol. 2009, 93, 72-76. [CrossRef]

10. Sierotzki, H.; Wullschleger, J.; Gisi, U. Point mutation in cytochrome b gene conferring resistance to strobilurin fungicides in Erysiphe graminis f. sp. tritici field isolates. Pestic Biochem. Physiol. 2000, 68, 107-112. [CrossRef]

11. Zheng, D.; Olaya, G.; Köller, W. Characterization of laboratory mutants of Venturia inaequalis resistant to the strobilurin-related fungicide kresoxim-methyl. Curr. Genet. 2000, 38, 148-155. [CrossRef]

12. Olaya, G.; \& Köller, W. Baseline sensitivities of Venturia inaequalis populations to the strobilurin fungicide kresoxim-methyl. Plant Dis. 1999, 83, 274-278. [CrossRef] [PubMed]

13. Fontaine, S.; Remuson, F.; Fraissinet-Tachet, L.; Micoud, A.; Marmeisse, R.; Melayah, D. Monitoring of Venturia inaequalis harbouring the QoI resistance G143A mutation in French orchards as revealed by PCR assays. Pest Manag. Sci. 2009, 65, 74-81. [CrossRef]

14. Küng Färber, R.B.; Chin, K.M.; Leadbitter, N. Sensitivity of Venturia inaequalis to trifloxystrobin. Pest Manag. Sci. 2002, 58, 261-267. [CrossRef] [PubMed]

15. Köller, W.; Parker, D.M.; Turechek, W.W.; Avila-Adame, C.; Cronshaw, K. A two-phase resistance response of Venturia inaequalis populations to the QoI fungicides kresoxim-methyl and trifloxystrobin. Plant Dis. 2004, 88, 537-544. [CrossRef]

16. Fiaccadori, R.; Cicognani, E.; Alberoni, G.; Collina, M.; Brunelli, A. Sensitivity to strobilurin fungicides of Italian Venturia inaequalis populations with different origin and scab control. Pest Manag. Sci. 2011, 67, 535-540. [CrossRef]

17. Mondino, P.; Casanova, L.; Celio, A.; Bentancur, O.; Leoni, C.; Alaniz, S. Sensitivity of Venturia inaequalis to trifloxystrobin and difenoconazole in Uruguay. J. Phytopathol. 2015, 163, 1-10. [CrossRef]

18. Stević, M.; Tamaš, N.; Miletić, N.; Vukša, P. Different toxicity of the strobilurin fungicides kresoxim-methyl and trifloxistrobin to Venturia inaequalis isolates from Serbia. J. Environ. Sci. Health B 2015, 50, 633-637. [PubMed]

19. Turan, C. Study of Venturia Inaequalis Sensitivity to Fungicides through Molecular and Biological Methodologies. Ph.D. Thesis, University of Bologna, Bologna, Italy, 2013.

20. Turan, C.; Nanni, I.M.; Tosun, N.; Collina, M. First report of QoI resistance in Venturia inaequalis causing apple scab in apple orchards in Turkey. Plant Dis. 2016, 100, 1016. [CrossRef]

21. Boehm, E.W.A.; Freeman, S.; Shabi, E.; Michailides, T.J. Microsatellite primers indicate the presence of asexual populations of Venturia inaequalis in coastal Israeli apple orchards. Phytoparasitica 2003, 31, 236-251. [CrossRef]

22. Gur, L.; Reuveni, M.; Cohen, Y. Occurrence and etiology of Alternaria leaf blotch and fruit spot of apple caused by Alternaria alternata f. sp. mali on cv. Pink Lady in Israel. Eur. J. Plant Pathol. 2017, 147, 695-708. [CrossRef]

23. Villani, S.M.; Cox, K.D. Heteroplasmy of the cytochrome b gene in Venturia inaequalis and its involvement in quantitative and practical resistance to trifloxystrobin. Phytopathology 2014, 104, 945-953. [CrossRef] [PubMed] 
24. Sallato, B.V.; Latorre, B.A.; Aylwin, G. First report of practical resistance to QoI fungicides in Venturia inaequalis (apple scab) in Chile. Plant Dis. 2006, 90, 375. [CrossRef]

25. Turechek, W.W.; Köller, W. Managing resistance of Venturia inaequalis to the strobilurin fungicides. Plant Health Prog. 2004, 5, 3. [CrossRef]

26. Köller, W.; Wilcox, W.F.; Parker, D.M. Sensitivity of Venturia inaequalis populations to anilinopyrimidine fungicides and their contribution to scab management in New York. Plant Dis. 2005, 89, 357-365. [CrossRef]

27. Fiaccadori, R.; Cicognani, E.; Abbatecola, A.; Collina, M.; Brunelli, A. Sensitivity of Venturia inaequalis to strobilurin fungicides in Italy. Commun. Agric. Appl. Biol. Sci. 2005, 70, 73.

28. Zheng, D.; Köller, W. Characterization of the mitochondrial cytochrome b gene from Venturia inaequalis. Curr. Genet. 1997, 32, 361-366. [CrossRef]

29. Ebrahimi, L.; Fotuhifar, K.B.; Nikkhah, M.J.; Naghavi, M.R.; Baisakh, N. Population genetic structure of apple scab (Venturia inaequalis (Cooke) G. Winter) in Iran. PLoS ONE 2016, 11, e0160737.

30. Gladieux, P.; Zhang, X.G.; Afoufa-Bastien, D.; Sanhueza, R.M.V.; Sbaghi, M.; Le Cam, B. On the origin and spread of the scab disease of apple: Out of central Asia. PLoS ONE 2008, 3, e1455. [CrossRef] [PubMed]

31. Chapman, K.S.; Sundin, G.W.; Beckerman, J.L. Identification of resistance to multiple fungicides in field populations of Venturia inaequalis. Plant Dis. 2011, 95, 921-926. [CrossRef]

32. Fiaccadori, R. Researches on methodologies to verify reduced sensitivities of Venturia inaequalis in field to difenoconazole and first indications of a survey in Italy. Am. J. Plant Sci. 2017, 8, 2056. [CrossRef]

33. FRAC (Fungicide Resistance Action Committee). FRAC Code List 2020: Fungicides Sorted by Mode of Action. Online Document. Available online: http:/ / www.frac.info (accessed on 6 September 2020).

34. Van den Bosch, F.; Paveley, N.; van den Berg, F.; Hobbelen, P.; Oliver, R. Mixtures as a fungicide resistance management tactic. Phytopathology 2014, 104, 1264-1273. [CrossRef] [PubMed]

35. Elderfield, J.A.; Lopez-Ruiz, F.J.; van den Bosch, F.; Cunniffe, N.J. Using epidemiological principles to explain fungicide resistance management tactics: Why do mixtures outperform alternations? Phytopathology 2018, 108, 803-817. [CrossRef] [PubMed]

36. Gisi, U. Synergistic interaction of fungicides in mixtures. Phytopathology 1996, 86, 1273-1279.

37. Gur, L.; Reuveni, M.; Cohen, Y. Control of Alternaria fruit rot in 'Pink Lady' apples by fungicidal mixtures. Crop Prot. 2020, $127,104947$. [CrossRef]

38. Reuveni, M.; Prusky, D. Improved control of moldy-core decay (Alternaria alternata) in Red Delicious apple fruit by mixtures of DMI fungicides and captan. Eur. J. Plant Pathol. 2007, 118, 349-357. [CrossRef] 